Working Paper

375

\title{
TAXING POWERS AND DEVELOPMENTAL ROLE OF THE INDIAN STATES: A STUDY WITH REFERENCE TO KERALA
}

\author{
R. Mohan \\ D. Shyjan
}


Working Papers published since August 1997 (WP 279 onwards) can be downloaded from the Centre's website (www.cds.edu) 
TAXING POWERS AND DEVELOPMENTAL ROLE OF THE INDIAN STATES: A STUDY WITH REFERENCE TO KERALA

\section{R. Mohan \\ D. Shyjan}

August 2005

We acknowledge the help rendered by Prof. K K Subrahmanian, Prof. P. Mohanan Pillai, Prof. Pushpangadan, Dr. K. N. Harilal, Dr. M. Kabir, Koshi P. Mathew, Dr. N. Ramalingam, Anil Kumar V K, and George Kutty, A special mention is due to Dr. T. M. Thomas Isaac for the interest shown in this paper and the comments given when this was presented in the I.S. Gulati Memorial Seminar held in Thiruvananthapuram on 29/05/2005. We thank the participants of the seminar at Centre for Development Studies on 23/05/2005 and of the I. S. Gulati Memorial seminar on 29/05/2005. Help rendered by Dr. H. Poornima Mohan and the lively interventions of Prashant Krishnan are also acknowledged. Usual disclaimer applies. 


\begin{abstract}
The study analyses whether the growing State Domestic Product (SDP) of Kerala since the latter half of the 1980s, has acted as a larger resource base for the State and finds that it has not. While the inability to fully tap the existing resource potential could be cited as a reason, the paper argues that the main constraint is the limited taxing powers of the States. The Study concludes that the power to tax the services should be devolved from the Centre to the States, lest the fiscal dispossession should affect the sustainability of achievements, which made the development experience of Kerala unique.
\end{abstract}

Key words: Revenue Receipts, Tax Effort, SDP

JEL Classification: E62, E69 


\section{General Backdrop}

The achievements of Kerala in Human Development Indicators have been widely discussed. The role of the state in acting as a prime mover in providing basic social goods like education and health as well as its initiatives in redistributive measures like land reforms has been internationally acknowledged (CDS: UN, 1975). The paradox of having a lower per capita income, while moving ahead in achievements like high literacy, low levels of infant mortality, high life expectancy etc. evoked the interest of many scholars and Kerala's development experience came to be widely discussed (Dreaze and Sen, 1989; Franke and Chasin, 1991). George (1999) had found that a slow expansion of the resource base was setting a limit to the development of Kerala. The study stated that the superstructure of an expanding welfare state was built on shaky foundations of an economy marked by low rates of growth. This situation changed since the latter half of the 1980s when the Kerala economy started growing at a faster pace. At present, the State has relatively higher per capita income levels and it ranks first in the human development indicators ${ }^{1}$. Kerala's achievements in human development indicators have often been compared with that of other nations in the world like China 
and Sri Lanka (Dreaze and Sen 1989, Osmani 1988). These comparisons bring out sharp contrasts between the performance of other States in the Indian Union vis-à-vis that of Kerala and the latter's comparable achievements with other nations.

While comparing a sub-national entity like Kerala with sovereign nations, it has to be taken note of that the powers of resource mobilisation (necessary for enabling the state to intervene in the fields of education, health and social security etc.) of the former are far more limited than that of the latter. This can act as an impediment to the state intervention at the sub-national level, for sustaining the achievements.

The paper analyses the fiscal scenario of Kerala since 1957-58, the year in which the first popular government assumed office after the State formation on 1st November 1956, till 2003-04, The aim is to examine the trends in the revenue receipts, revenue expenditure and its components like education and health, and trace reasons on how the lurking signals of fiscal imbalances evolved into persistent trends in the later years. The revenue deficit has become chronic and Balance from Current Revenues (BCR) has turned negative ${ }^{2}$. The focus of the study is to examine the question whether the faster economic growth has acted as an expanding resource base enabling Kerala to maintain and upgrade the quality of the achievements.

\section{Revenue Receipts of Kerala}

The revenue receipts of Kerala, like all the States in India, consist mainly of tax and non-tax revenues. A part of this is mobilised by the State's own efforts and the remaining is tax and grant devolution from the Centre. In addition to revenue receipts, there are also capital receipts, which include loans from the Centre and market borrowings.

As regards Central resources, the Finance Commissions constituted every five years, as required under the Article 280 of the Constitution of India, recommend devolution of a portion of the tax revenues of the 
Centre to the States according to the criteria devised by them ${ }^{3}$. The other component of the revenue receipts is the non-tax revenue, which consists of the receipts from the social, economic and other services provided by the State and Central grants. The Central grants consist of Plan and nonPlan grants, the former being devolved by the Planning Commission and the latter by the Finance Commission ${ }^{4}$.

Out of the Revenue Receipts, 81 percent was from tax revenue during the period 1990-91 to 2002-03. The proportion of tax revenues in revenue receipts is increasing over the period of time. The State's own tax revenues consisted of 77 percent of the tax revenues during the same period. In the Own tax revenue, the largest source was the Sales Tax, which has been replaced by Value Added Tax (VAT) with effect from 1st April 2005. We will now discuss the measurement of tax effort, which is nothing but the amount mobilised as taxes as a proportion of its economic base, which has to be estimated by a proxy measure,

Table 1. Component of Revenue Receipts and Tax Revenue

\begin{tabular}{l|c|c|c}
\hline Period & $\begin{array}{c}\text { Tax Revenue/ } \\
\text { Total revenue }\end{array}$ & $\begin{array}{c}\text { Own tax } \\
\text { revenue/ } \\
\text { Tax Revenue }\end{array}$ & $\begin{array}{c}\text { Sales Tax / } \\
\text { Own Tax } \\
\text { Revenue }\end{array}$ \\
\hline 1957-58 to 1969-70 & 0.59 & 0.75 & 0.44 \\
1970-71 to 1979-80 & 0.65 & 0.71 & 0.57 \\
1980-81 to 1989-90 & 0.75 & 0.72 & 0.63 \\
1990-91 to 2002-03 & 0.81 & 0.77 & 0.70 \\
\hline
\end{tabular}

Source: Computed from RBI Bulletin, various issues

\section{Tax Effort}

\section{a) Economic base of taxes}

In this section, we discuss the choice of a proxy for the economic base of taxation for Kerala. At the national level, taxes are levied on the 
manufacturing output (Central excise), on value of imports (Customs Duty), on corporate profits (Corporation tax) and on personal incomes above a limit (Personal Income Tax). Manufacturing output, Corporate and Personal incomes are components of Gross Domestic Product (GDP). Hence the tax effort of the Central Government is measured in terms of tax-GDP ratio. At the States' level, the taxes levied on trade of commodities and are essentially a function of consumption expenditure, with of course the exclusion of subsistence and non-taxable consumption. But consumption is again a function of income and hence State Domestic Product (SDP) can be taken as the economic base for taxes. But in the Kerala context, another measure, which enlarges the SDP by adding the remittances by the non-residents, has been suggested as the economic base for taxes, as the latter, especially from the Gulf, is a very important inflow into the State through banking as well as non-banking channels. [See Sebastian 1994, Kannan and Hari (2002), Rakhee (2003)]. We are not adopting this as the tax base for the following reasons

1) Though the income from remittances can be the source for consumption expenditure on goods and services within the geographical boundary of the State, this ought to be reflected in the output of the economy. ${ }^{5}$

2) There can be leakage of remittance induced spending and part of it may be spent outside the State and this will get reflected in the other States' SDP. ${ }^{6}$

Because of these two reasons, addition of remittances from abroad will an abnormal enlargement of the economic base of taxation. If we attempt to use consumption expenditure data, comparable year-wise series is not available. The results of the thin rounds of the NSSO survey are not comparable with those of the quinquennial rounds and there are 
limitations in the consumption expenditure data itself (Sebastian, 1994; Gulati, 1994). Taking into consideration all these measurement problems, we prefer the SDP as the economic base of taxation, as this is a standard measure and easily comparable across time and with that of other States. We use the SDP at current prices ${ }^{7}$ and analyse the movement of own tax-SDP ratios and the relations between the growth rate of SDP and tax revenue.

\section{b) Kerala's Tax Effort}

The own tax-SDP ratio of Kerala has risen over the decades, but has been increasing at a decreasing rate since the 1990s. It has improved from 4.12 during the 1960 s to 5.12 in the 1970 s 8.44 during the $1980 \mathrm{~s}$ and 9.39 during the period $1990-91$ to $2001-02^{8}$. This increase captures the response to the increase in tax base, changes in tax structure and the structural transformation of the SDP. But another indicator of tax effort, ${ }^{9}$ that is the relationship between the growth rates of tax revenue and $\mathrm{SDP}^{10}$ shows that the increases in SDP has not been acting as an increasing resource base for the government (Table 2). To elaborate this further, though tax-SDP ratio has risen, it has increased at a decreasing rate in the 1990s. If this decrease in rate of increase continues, it can lead to a fall in tax-SDP ratio in future. The Twelfth Finance Commission report while prescribing normative buoyancy rates for States has fixed a higher rate of 1.30 for Kerala compared to many other States. A higher normative buoyancy is fixed when the tax-SDP ratio needs to rise more when per capita SDP is high, This is considered necessary by the Twelfth Finance Commission, if the tax-SDP ratio should not fall in the future. When we test the buoyancy of own tax revenue with another base, i.e. consumption expenditure $^{11}$ (the limitations of which have been separately mentioned), it has declined from 1.57 in the 1970 s, to 1.42 in the 1980 s and to 1.08 in the $1990 \mathrm{~s}^{12}$. 
Table 2. Growth Rates of Tax Revenues and SDP 1960-61 to 2001-02

\begin{tabular}{l|c|c|c}
\hline Period & $\begin{array}{c}\text { Growth Rate } \\
\text { of Own Tax } \\
\text { Revenue/ } \\
\text { Growth Rate } \\
\text { of SDP }\end{array}$ & $\begin{array}{c}\text { Growth Rate } \\
\text { of Sales tax/ } \\
\text { Growth rate } \\
\text { of SDP }\end{array}$ & $\begin{array}{c}\text { Growth Rate } \\
\text { of Sales tax/ } \\
\text { Growth Rate } \\
\text { of Trade and } \\
\text { manufacturing } \\
\text { sub-sectors }\end{array}$ \\
\hline $1960-61$ to $1964-65$ & 1.76 & 2.14 & ---- \\
$1965-66$ to $1969-70$ & 0.87 & 0.75 & ---- \\
$1970-71$ to $1974-75$ & 1.38 & 1.62 & 1.30 \\
$1975-76$ to $1979-80$ & $2.22 *$ & 1.85 & 1.75 \\
$1980-81$ to $1984-85$ & 1.35 & 1.50 & 1.55 \\
$1985-86$ to $1989-90$ & 1.31 & 1.35 & 1.26 \\
$1990-91$ to $1994-95$ & 0.97 & 1.12 & 1.35 \\
$1995-96$ to $2001-02$ & 0.89 & 1.16 & 0.98 \\
\hline
\end{tabular}

Source: Computed from RBI Bulletins, various issues.

* Note: This very high buoyancy for this period seems exceptional and it was seen that there was wide growth fluctuation in the tax revenues. For finding out reasons, an analysis of the change in prices of commodities yielding tax revenue will have to be looked at in detail.

Figure 1. Trend Growth Rate of the State Domestic Product at Current prices 1960-61 to 2001-02

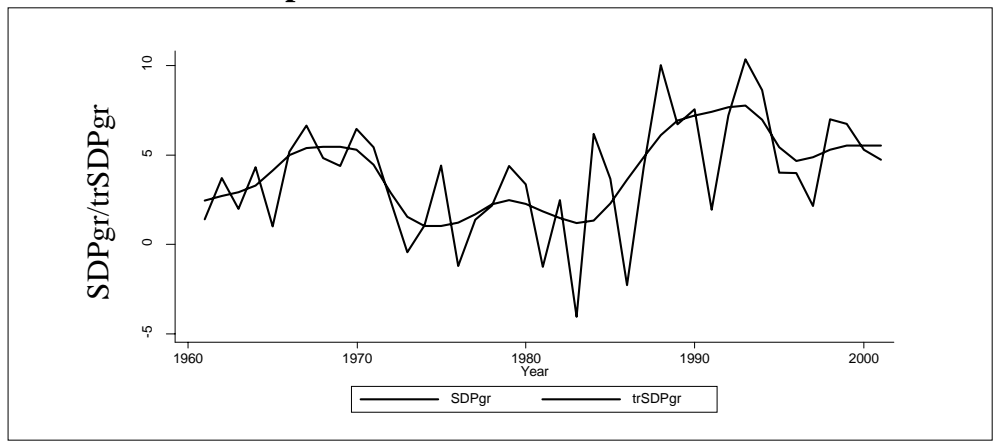

Source: Computed from Domestic Product of States of India, EPW Research Foundation 
Figure 2. Sectoral composition of SDP at 1993-94 Prices, spliced Series

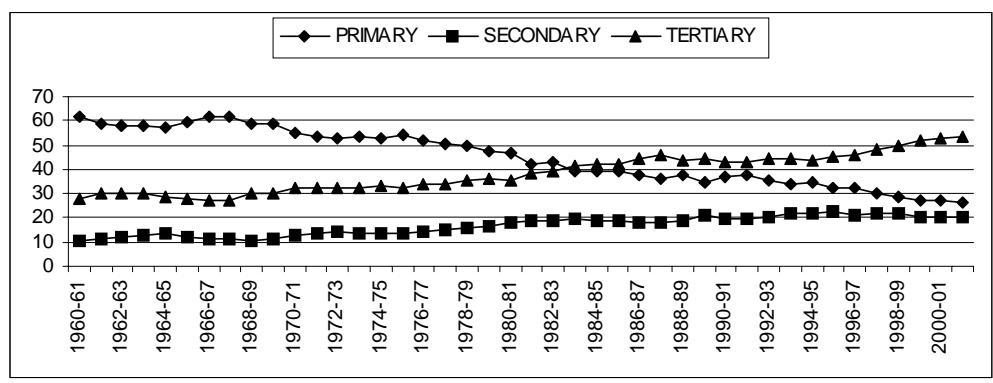

Source: Computed from Domestic Product of States of India, EPW Research Foundation

Figure 3. Trend of own- tax SDP-ratio

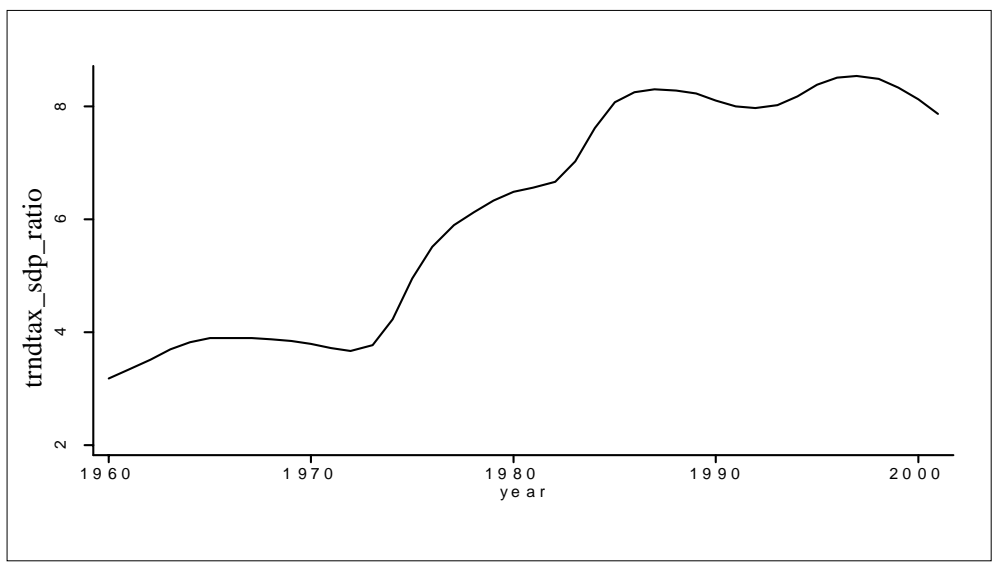

Source: Computed from RBI Bulletin various issues and Domestic Product of States of India, EPW Research Foundation.

\section{Tax Buoyancy}

In the Kerala context, it is during the period when SDP has grown faster (the underlying trend ${ }^{13}$ rises from the latter half of the 1980 s to early half of the 1990s), that the ratio of growth of own tax revenue and growth of SDP has fallen. The fall is discernible since the $1990 \mathrm{~s}^{14}$. 
A testable hypothesis that can be advanced is that though the Kerala economy has been growing, the fastest growing sub-sector, i.e. the services sector, is outside the taxing powers of the States. Under the Indian Constitution, States can tax the sale of commodities and not the services, except a few ones like electricity duty, entertainment tax etc. As a State within the Indian Union, Kerala is thus Constitutionally barred from taxing the fastest growing sectors of its economy. This particular pattern of growth itself has evolved out of cross- border and inter-State remittances and has resulted in the State having sectors and sub-sectors, which grow fast, but are out of its tax net (for example, Telecommunications, Banking and Insurance and a wide range of services included in 'Other Services').

There was a structural shift in the State Domestic Product with the share of the primary sector falling since the second half of the 1970s. It ceased to be the dominant sector since the early half of the 1980s. The share of the tertiary sector, in which the sub-sector trade is the dominant one, started rising. Though the share of the secondary sector also has been rising, it is below that of the other two sectors. This shift gets reflected in the trend of tax-SDP ratio, which shows a rise in the same period and then flattens out. This flattening could be mainly due to the fact that the faster growing components of the service sector are outside the taxing powers of the State. [See Figure 3]

This brings us to addressing the question of devolving the power to tax the services to the States. We will discuss the economic and Constitutional issues involved in this after examining whether the existing tax base of the State is being mobilised fully.

\section{Non-Mobilisation from Existing Tax Base- An Empirical Examination}

Sales tax, which is primarily a tax on consumption, is the major source of tax revenue for all the States including Kerala. Out of the sub- 
sectors of SDP, the Manufacturing and Trade can be taken as a proxy base for sales $\operatorname{tax}^{15}$. The growth rate and underlying trend of the sales tax base for the period 1971-72 to 2001-02 ${ }^{16}$, shows an upward movement in the second half of the 1970s. This is accompanied by a rise in underlying trend of sales tax growth. The trend in the growth rate of sales tax shows two upward shifts, one in the early 1970s and the other in the early 1990s. But the rise in the trend of the tax base in the latter half of the 1980s is not seen reflected in the trend of the growth in sales tax revenue. It grows only in the beginning of the 1990s and then starts declining. This rise could be due to petroleum price hike ${ }^{17}$, which will not get reflected in the domestic tax base. There is a decline in trend growth rate of sales tax since the latter half of the 1990s. In addition to the decline in the trend in the growth of the base, a rising organised resistance to tax enforcement could be another reason. The political economic ramifications of these will have to be studied separately. A commodity wise analysis of tax potential and actual as done by the Taxation Enquiry Committee (1969) and Sebastian (1994) may throw more light on the extent of sales tax evasion, but it is outside the scope of this paper. Other studies have also concluded that there is considerable tax evasion in Kerala (Rakhee 2003, Ravi Raman 2004).

\section{Figure 4. Trend Growth Rate of Manufacturing and Trade sectors 1970-71 to 2001-02}

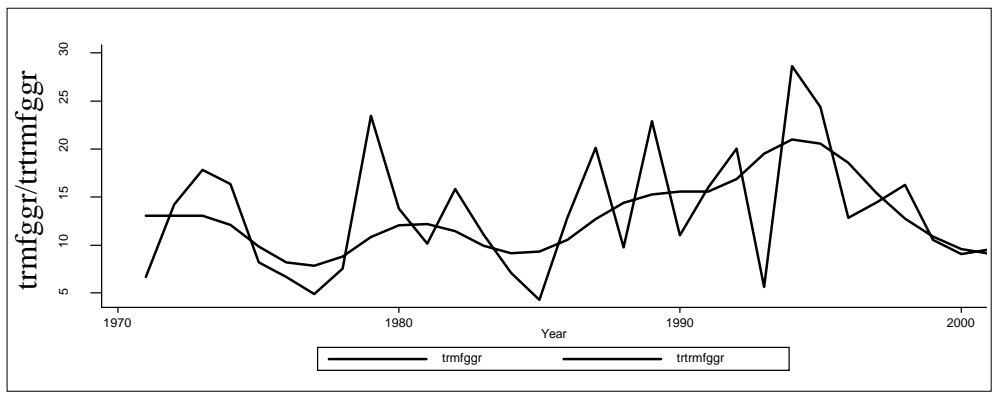

Source: Computed from Domestic Product of States of India, EPW Research Foundation 
Figure 5. Trend Growth Rate of Sales Tax Revenue 1960-61 to 2003-04

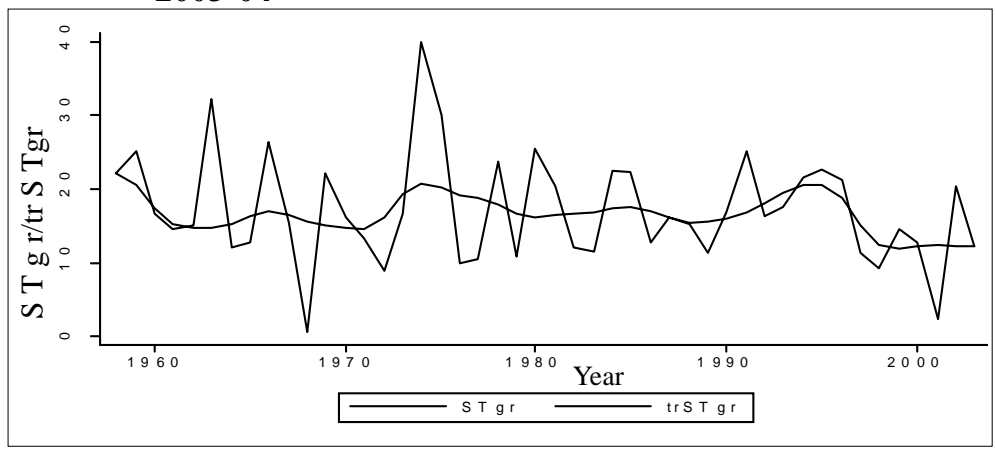

Source: Computed from RBI Bulletin, various issues

Pushpangadan (2003), while analysing the impact of remittances on economic growth has stated that though the Marginal Propensity to Consume (MPC) is coming down, especially for the remittances, the consumer demand for durable goods is increasing. The study found that the inter-regional trade is predominant. This should have formed the base for sales tax, which is essentially a first point levy within the State. It is here that the problem of widespread evasion needs to be considered. Had it not been there, tax revenue should have been more buoyant.

But tax evasion is not a Kerala specific phenomenon and all States as well as the Centre face this problem. In relative performance, Kerala's tax-SDP ratio has been better than that of many other States, which have a higher per capita income. As we do not have a normative standard for evasion or even authentic studies on comparable levels of tax evasion at the States' and the Central level, it can be stated that going by the higher tax-SDP ratio, Kerala's levels of evasion cannot be considered higher than that prevailing in other States. Though it needs to be emphasised that the tax potential has to be tapped in a better way, the suggestion that tax evasion has to be completely checked in Kerala, or in any other State, will not be a realistic one. Here, the argument for enlarging the taxing powers of the States by including services in their tax net assumes significance. 


\section{Devolving Service Taxation to the States}

\section{a) Constitutional Issues}

In Kerala, the fastest growing sub-sectors within the services sector are the Transport and Communications, Banking and Insurance and Other services and all these are outside the taxing powers of the States.

Taxing of services was not conceived originally under the Constitution. On the recommendations of the Chelliah Committee Report (1993) on tax reforms, the Centre started selectively taxing the services, using the power in the Residuary List of the Constitution. The service tax levied by the Union was part of the divisible pool and was shareable with the States on the recommendations of the Finance Commissions. The Constitutional amendment, which introduced the Article 268A made taxing of services part of the Union list. It will hereafter not be part of the divisible pool under Article 270 of the Constitution, and it will be taxed according to separate norms to be laid down, in which collection and appropriation of taxing of services between the Centre and the States will be mentioned. The devolution of taxing powers of the services to the States in toto will require the deletion of the Article 268A and a fresh Constitutional amendment. Another way will be to substantially devolve the power to tax services to the State in the separate norms to be laid down by the Parliament. Though a more difficult route, the former seems to be a better solution in the long-term ${ }^{19}$.

\section{b) Economic Reasons}

In a federal set-up where the Union and the Provincial entities have distinct taxing powers, generally the more elastic and mobile tax bases are with the former and taxes like consumption tax are with the latter. But this can lead to vertical inequity between the Union and the Provinces, especially when the latter has higher expenditure obligations. The devolution of taxes from the Union to the Provinces is the mechanism adopted for ensuring vertical equity. The reason for mobile and elastic bases to be with the Union is that tax competition between provinces would otherwise result in shifting and erosion of tax bases. In the Indian 
federal set up, the elastic and more mobile taxes like the Personal Income Tax, Corporate Tax, Excise Duty and Customs Duty are with the Centre. The more inelastic and less mobile Sales Tax is with the State Governments. Tax on services is levied on the services performed and is not a mobile tax base. On the basis of economic reasoning, this tax can be devolved to the States, as the shifting of this tax base is not easily possible. The Centre is taxing the income earned from services sector in Personal Income tax and Corporation tax and also levying services tax, which is essentially a tax on the rendering of the service. If the latter is handed over to the States, it will help them to tax the fastest growing sector of their economy.

\section{Non-Tax Revenues}

With tax revenues being 81 percent of the total revenue during 1990-91 to 2002-03, the non-tax revenues occupy a minor proportion of the total revenue receipts. Out of the non-tax revenue, Central grants occupy a substantial component. Table 3 shows the proportion of Central grants in non-tax revenue

Table 3: Grants as a proportion of Non-Tax and Total Revenue

\begin{tabular}{c|c|c|c}
\hline Period & $\begin{array}{c}\text { Central Grants/ } \\
\text { Non-Tax Revenue }\end{array}$ & $\begin{array}{c}\text { Central Grants/ } \\
\text { Total Revenue }\end{array}$ & $\begin{array}{c}\text { Non-Tax } \\
\text { Rev/SDP }(\%)\end{array}$ \\
\hline 1960-61 to $1964-65$ & 0.47 & 0.18 & 3.36 \\
$1965-66$ to $1969-70$ & 0.57 & 0.22 & 3.88 \\
$1970-71$ to $1974-75$ & 0.49 & 0.18 & 3.50 \\
$1975-76$ to $1979-80$ & 0.44 & 0.15 & 4.53 \\
$1980-81$ to $1984-85$ & 0.38 & 0.10 & 3.86 \\
$1985-86$ to $1989-90$ & 0.55 & 0.13 & 3.80 \\
$1990-91$ to $1994-95$ & 0.56 & 0.12 & 3.55 \\
$1995-96$ to $2002-03$ & 0.54 & 0.09 & 2.38 \\
\hline
\end{tabular}

Source: Computed from RBI Bulletin, various issues 
As a proportion of non-tax revenue, the contribution of grants increased in the mid-1980s and stagnated there after, while as a proportion of total revenue it declined. The non-tax revenue/ SDP ratio declined during the period 1960-61 to 2002-03. During the second sub-period in the 1970s proportion of Central grants to non-tax revenue fell, but the proportion of non-tax revenue to SDP went up, implying that own nontax revenue improved during this period. During the 1980s, the reverse happened, the Central grants' share improved but proportion of non-tax revenue to SDP fell, implying that own non-tax revenue fell. During the 1990s, both central grants and own non-tax revenues have fallen.

As far as the own-non tax revenues are concerned, its share in the total revenue receipts have fallen in the four decades, the 1960s, the 1970 s, the 1980s and the 1990s. Kerala's proportion of own non-tax revenue to total revenue is less than the all-States' proportion by almost 50 percent. (See Table 4) The share of the revenue from forests, which constitutes a substantial portion of the own non-tax revenues of the State, has been coming down. The White Paper on State Finances (2001) and the Report of the Resources Commission (1993) discusses this in detail and state that the environmental regulations as well as inadequate exploitation of the potential as the reason for this. The former estimates that an additional Rs. 50 crores can be mobilised from this source. Receipts from other sources like interest, fees from social and economic services, revenue from leased land etc. have been described as far below potential. Since the head-wise details have been discussed in these reports we are not going into them here. Suffice it to say that, the government can attempt to take steps to mobilise Rs. 425 crores from the various heads, as outlined in the White Paper on State Finances ${ }^{20}$. But this will only cover one-fifth of the negative Balance from Current Revenues. 
Table 4: Own Non-Tax Revenues to Kerala's Revenue Receipts

\begin{tabular}{c|c|c|c}
\hline Period & $\begin{array}{c}\text { Own Non-tax } \\
\text { Revenue/Total } \\
\text { Revenue Receipts }\end{array}$ & $\begin{array}{c}\text { Non-Tax Revenue/ } \\
\text { Total Revenue } \\
\text { Receipts \# }\end{array}$ & $\begin{array}{c}\text { Revenue from } \\
\text { forests/Own } \\
\text { Non-Tax Revenue }\end{array}$ \\
\hline $1960 \mathrm{~s}$ & 18.19 & 38.6 & 27 \\
$1970 \mathrm{~s}$ & $18.22(19.00)$ & 35.12 & 32 \\
$1980 \mathrm{~s}$ & $12.59(17.00)$ & 24.41 & 27 \\
$1990 \mathrm{~s}$ & $8.66(15.00)$ & 19.39 & 25 \\
$2000-01$ to & $6.66(13.00)$ & 16.71 & 22 \\
$2003-04$ & & & \\
\hline
\end{tabular}

Source: Computed from RBI Bulletin, various issues.

Note: \# This includes Central plan and non-plan grants. The figures within parenthesis are the ratio of all States' own non-tax revenue to total revenue receipts.

\section{Trends in Central Devolution of Grants and Taxes to Kerala}

The Central grants include Plan and non-Plan grants. Almost half of the non-tax revenue of the State is from Central grants. Grants from the Centre are devolved by the Finance Commission, which devolves nonPlan grants, Planning Commission, which devolves Plan grants and various Central Ministries, which give matching grants or discretionary grants.

The grants under Article 275 of the Constitution are devolved on the recommendations of the Finance Commissions. Under this, if a State has a deficit in non-Plan revenue account after devolution of taxes, grants will be given to bridge this deficit. The Ninth Finance Commission adopted a normative method (where in estimated receipts and expenditure are projected for the five-year period) to determine the deficits in revenue account and recommended grants based on this approach. Prior to this, the Finance Commissions used to revise the estimates submitted by the States and the non-Plan revenue deficit used to be filled by devolving grants under Article 275. The Finance Commissions after the Third 
looked at only the non-Plan revenue account. The Ninth Finance Commission looked at the revenue deficit as a whole and made recommendations for allotting non-Plan and Plan grants as well ${ }^{21}$. Though the subsequent Finance Commissions have followed the normative method of assessing expenditures and revenues, they have confined the grants under Article 275 to deficits in the non-Plan revenue account only. In addition to Article 275, the Article 282 empowers the Union or a State to make a grant for any public purpose, irrespective of the question whether the purpose is one over which the grantor has legislative competence. It is using this residuary power that Planning Commission and the Ministries devolve grants. Thee ratio of the quantum of the non-Plan and Plan grants for Kerala has come down from 0.42 in the 1970 s to 0.12 in the 1980 s and reached 0.19 in the 1990 s till 200203 . The grants under the residuary power far exceed the statutory grants devolved by the Finance Commission. On an examination of the nonPlan revenue deficits projected by the Eleventh Finance Commission under the normative method and the actuals as per the budget, it can be seen that Kerala has not been getting grants under Article 275 from the Finance Commission despite having deficits in the non-Plan revenue account. The normative estimates of the Finance Commissions have been wide off the mark when compared with the actuals.

Table 5: Normative Estimates and Actual Non-Plan Revenue surplus/Deficits (in lakhs)

\begin{tabular}{c|c|c}
\hline Period & Eleventh FC & Actuals (as per Accounts) \\
\hline $2000-01$ & 28946 & -170342 \\
$2001-02$ & 90654 & -166965 \\
$2002-03$ & 96082 & -181111 \\
$2003-04$ & 190573 & -201925 \\
$2004-05$ & 306812 & $-230640(\mathrm{RE})$ \\
Total 2000-05 & 713067 & $-107723(\mathrm{BE})$ \\
\hline
\end{tabular}

Source: Report of the Eleventh Finance Commission and RBI Bulletins, Various issues. 


\begin{tabular}{l|c|c|c|c|c|c|c}
\hline & Tax & $\begin{array}{c}\text { In lakhs } \\
\text { under } \\
\text { Article } 275\end{array}$ & Others & $\begin{array}{c}\text { Total Tax } \\
\text { revenue }\end{array}$ & $\begin{array}{c}\text { Non tax } \\
\text { revenu e }\end{array}$ & $\begin{array}{c}\text { Central tax } \\
\text { devolution/ } \\
\text { Total tax } \\
\text { revenue }\end{array}$ & $\begin{array}{c}\text { Central grants } \\
\text { grants/Non- } \\
\text { tax revenue }\end{array}$ \\
\hline $1957-58$ to $1960-61$ & 2203 & 817 & 78 & 8719 & 5592 & 0.25 & 0.16 \\
$1961-62$ to $1965-66$ & 5586 & 2775 & 115 & 19995 & 12521 & 0.28 & 0.23 \\
$1966-67$ to $1968-69$ & 5025 & 6264 & 90 & 20586 & 15653 & 0.24 & 0.41 \\
$1969-70$ to $1973-74$ & 18329 & 5016 & 145 & 56511 & 30278 & 0.32 & 0.17 \\
$1974-75$ to $1978-79$ & 31801 & 22307 & 150 & 125537 & 73741 & 0.25 & 0.30 \\
$1979-80$ to $1983-84$ & 86056 & 0 & 210 & 278093 & 104596 & 0.31 & 0.00 \\
$1984-85$ to $1989-90$ & 196301 & 20 & 1560 & 735224 & 217725 & 0.27 & 0.01 \\
$1990-91$ to $1994-95$ & 333923 & 24598 & 0 & 1338446 & 377781 & 0.25 & 0.07 \\
$1995-96$ to $1999-2000$ & 645087 & 7470 & 0 & 2809417 & 574097 & 0.23 & 0.01 \\
$2000-01$ to $20005-06 *$ & 1244580 & 0 & 0 & 6013197 & 440984 & 0.21 & 0.00 \\
\hline
\end{tabular}

Source: Budget in Brief 2005-06

Note * Includes revised estimate for 2004-05 and budget estimate for 2005-06. 
States also get a share of taxes from the Centre. The traditional devolution criteria like Area, Distance and Population have not been favourable to Kerala. The share of Central taxes as a proportion of total revenues has come down during the 1990s, especially after the Eleventh Finance Commission, which had to adopt substantially different standards for tax devolution. In the 1990s, when the economy has grown fast, the State's own tax revenue as well as Central share of taxes has come down creating a constraint in the receipts side.

Table 6 shows the tax and grant devolution by the various Finance Commissions from the second to the Eleventh. It can be seen that the devolution of Central tax revenues have declined as a proportion of the State's total tax revenues. The trend of the general-purpose grants under Article 275 has declined sharply after the Ninth Finance Commission and has been reduced to nil, leaving the State with no grant for covering the negative BCR. This implies that the plan size of the State was entirely financed by borrowings save the grant component, which is 30 percent of plan fund devolution under the Gadgil formula. Since the revenue component of the plan expenditure far exceeds this, much of the plan revenue expenditure is also financed by borrowing. This puts pressure, as the debt burden of the State rises and since Kerala has a substantial portion of high cost debt, the burden of committed revenue expenditure, through interest payments rises.

Let us also briefly discuss the two tax devolution criteria, which are considered as incentives for better Tax Effort and Fiscal Self-Reliance. The Tenth, Eleventh and the Twelfth Finance Commissions have used these two along with other criteria for devolution of tax receipts of the Centre. The Commissions assigned the following weights to these criteria. 
Table 7: Weights in Tenth, Eleventh and Twelfth Finance Commissions for Incentive Criteria

\begin{tabular}{l|c|c|c}
\hline \multicolumn{1}{c|}{ Criteria } & Tenth & Eleventh & Twelfth \\
\hline Tax Effort & 10 & 5.0 & 7.5 \\
Fiscal Self Reliance & - & 7.5 & 7.5 \\
\hline
\end{tabular}

Source: Report of the Finance Commissions

As regards tax effort, the tax-GSDP ratios of the respective States were compared after giving a weightage for the inverse of per capita GSDP. The Tenth Finance Commission weighted the tax-SDP ratio by inverse of per capita GSDP, the Eleventh Finance Commission reduced

Table 8: Tax-GSDP Ratios of States in India- Three-Year Average of 1999-00 to 2001-02

\begin{tabular}{c|c|c|c}
\hline Tamil Nadu & 8.63 & Orissa & 5.16 \\
Karnataka & 8.18 & Himachal Pradesh & 5.04 \\
Kerala & 7.81 & Jharkhand & 4.85 \\
Haryana & 7.78 & Assam & 4.29 \\
Gujarat & 7.74 & Bihar & 4.24 \\
Maharashtra & 7.49 & West Bengal & 4.22 \\
Andhra Pradesh & 7.27 & Sikkim & 4.04 \\
Goa & 6.8 & Jammu \& Kashmir & 3.92 \\
Punjab & 6.73 & Meghalaya & 3.25 \\
Chhattisgarh & 6.38 & Tripura & 2.12 \\
Rajasthan & 6.14 & Arunachal Pradesh & 1.21 \\
Uttaranchal & 5.88 & Nagaland & 1.17 \\
Madhya Pradesh & 5.49 & Manipur & 1.14 \\
Uttar Pradesh & 5.45 & Mizoram & 0.79 \\
\hline
\end{tabular}

Source: Report of the Twelfth Finance Commission. 
the weight inverse of per capita GSDP to 0.5 and the Twelfth Finance Commission used the square root of the inverse of the per capita GSDP as the weight. The weight based on inverse of per capita GSDP is given so that a poorer State gets more weightage for better exploitation of its tax base. Kerala, which ranks sixth among the States in per capita GSDP, has a tax-SDP ratio of 7.8 percent, ranking third below Tamil Nadu and Karnataka during the reference period of the Twelfth Finance Commission.

The Tenth, Eleventh and the Twelfth Finance Commissions calculated the Tax Effort by scaling down the tax-GSDP ratios of the States by different forms of inverse of per capita GSDP.

Scaled Tax effort of each State $T_{i}=$ Tax-GSDP ratio of the State $X$ different forms of inverse of GSDP (inverse, $0.5 \mathrm{X}$ inverse and square root of the inverse)

Tax Effort measured by the Finance Commission $\mathrm{T}_{\mathrm{E}}=\mathrm{T}_{\mathrm{i}} / \sum \mathrm{Ti}$, where $\sum \mathrm{T}_{\mathrm{i}}$ is the aggregate of scaled tax efforts of all States.

It can be seen that Kerala has benefited by the application of square root of inverse of per capita income, whereas States with poorer per capita income have not benefited from this. The overall picture of all States is complex as the tax effort criteria used by the Finance Commission comprises the interaction effect of tax -SDP ratios, per capita GSDP and the weights assigned to the tax effort criteria. Kerala, which is third when inter-State comparison of tax-SDP ratios is made, goes to the sixth position in tax effort, i.e. when scaled down by the square root of the inverse of per capita GSDP and given weightage of 7.5 percent. Had the scaling down criteria of the Tenth and the Eleventh Finance Commissions been used by the Twelfth Finance Commission, Kerala's position would have been 13 'th. The middle income States like Tamil Nadu and Karnataka, which are on the top would have occupied 9'th and 10 'th positions respectively had scaling down by the previous 
Commissions been used. The poor income States like Bihar and Uttar Pradesh have moved down from the top position in the present scaling down weightage. An analysis of cross-State comparison on the basis of these criteria is outside the scope of our study. The point to be noted here is that though rising per capita incomes have brought Kerala to the group of high income States, its tax-GSDP ratio is behind that of Tamil Nadu and Karnataka during the reference period of the Twelfth Finance Commission. This is an indication of the falling tax buoyancy due to the slowing down of the increase in tax-GSDP ratio. As stated earlier, the report of the Twelfth Finance Commission has recognised and prescribed a higher rate of buoyancy for Kerala in comparison to other States for the period 2005-10.

As regards the other incentive criterion, Fiscal Self Reliance, Kerala's position is 16 'th among all States. This is despite the fact that Kerala has been better than many other States in meeting revenue expenditure from own revenue receipts. The methodology of computation of Fiscal Self Reliance is as follows

The base period ratio of own revenue receipts and revenue expenditure of a State is taken and its ratio with the all States' ratio of own revenue receipts and revenue expenditure is computed. The same is done for the reference period. Then the improvement over and decline from the base period ratio to the reference period ratio is seen. If there is deterioration, the index of Fiscal Self Reliance will fall below one and if there is an improvement the index will be above one. For example, let us assume

The base period ratio of own revenue receipts to revenue expenditure of $i^{\prime}$ th State $=0.75$

The base period ratio of all States' own revenue receipts to revenue expenditure $=0.65$

The base period ratio for the $i^{\prime}$ th State $=0.75 / 0.65=1.15$

The reference period ratio of own revenue receipts to revenue expenditure of $i$ 'th State $=0.73$ 
The reference period ratio of all States' own revenue receipts to revenue expenditure $=0.64$

The reference period ratio for the i'th State $=0.73 / 0.64=1.14$

Fiscal Self Reliance Criterion $=1.14 / 1.15=0.99$

The base period ratio of own revenue receipts to revenue expenditure of j'th State $=0.40$

The base period ratio of all States' own revenue receipts to revenue expenditure $=0.65$

The reference period ratio for the $j$ 'th State $=0.40 / 0.65=0.61$

The reference period ratio of own revenue receipts to revenue expenditure of $j$ 'th State $=0.42$

The reference period ratio of all States' own revenue receipts to revenue expenditure $=0.64$

The base period ratio for the $j^{\prime}$ th State $=0.42 / 0.64=0.65$

Fiscal Self Reliance Criterion= 0.65//0.61= 1.07

The Fiscal Self-Reliance Index of a State with a far less own revenue receipts to revenue expenditure ratio can be better than that of a State which meets substantially a higher amount of revenue expenditure from own revenue receipts. Kerala's Fiscal Self-Reliance indicator computed by the Twelfth Finance Commission is 0.97 as against 1.09 for the period of the Eleventh Finance Commission award. The slowing down of own revenue to revenue expenditure between the base and reference periods of the Twelfth Finance Commission. i.e. 1993-96 to 2000-2003, can be due to 1) fall in tax buoyancy resulting in tax-SDP ratio rising at a decreasing rate 2) low mobilisation of non-tax revenues, 3 ) increase in revenue expenditure, which have among many reasons a) the impact of the Fifth pay Commission on salaries and pensions and $b$ ) increase in revenue expenditure due to classification of all grants devolved to local bodies (even though a portion of them might have been spent for 
capital purposes) as revenue expenditure. In any case, Kerala has not gained at all from this criterion, inspite of it meeting a higher proportion of revenue expenditure from own revenue receipts, when compared to many other States. The analysis of these two incentive criteria clearly shows that Kerala is being pushed backwards in Central devolution of taxes based on them.

\section{Expenditure Trends of Kerala}

The underlying trend of revenue expenditure shows that the movement is cyclical from the 1960s till the 1990s. The regular upswings of approximately five-year cycles can be due to the impact of regular institutionalised pay revisions', rise in committed non-plan revenue expenditure on completion of plan periods etc. The five yearly averages of growth rates of revenue expenditure since the 1960s are given in Table 9.

Figure 6: Trend in Growth Rate of Revenue Expenditure in Kerala: 1958-59 to 2003-04

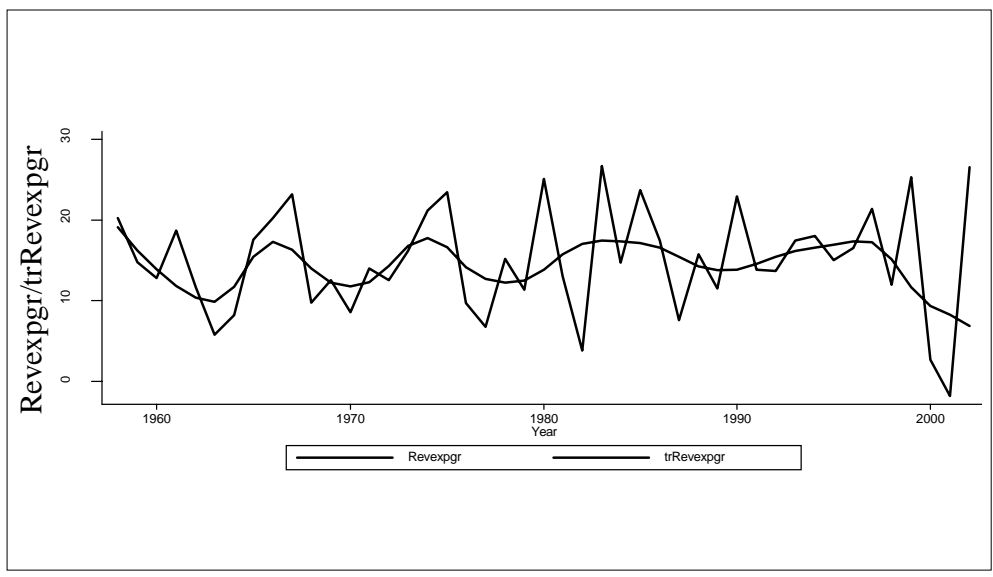

Source: Computed from RBI Bulletin, various issues 
Table 9: Growth Rate and Proportion of Revenue Expenditure to SDP

\begin{tabular}{c|c|c}
\hline \multicolumn{1}{c|}{ Period } & $\begin{array}{c}\text { Average Growth } \\
\text { rate of Revenue } \\
\text { Expenditure }\end{array}$ & $\begin{array}{c}\text { Revenue } \\
\text { Expenditure /SDP }\end{array}$ \\
\hline $1960-61$ to $1964-65$ & 11.42 & 7.67 \\
$1965-66$ to $1969-70$ & 16.66 & 8.44 \\
$1970-71$ to $1974-75$ & 14.50 & 9.14 \\
$1975-76$ to $1979-80$ & 13.30 & 11.47 \\
$1980-81$ to $1984-85$ & 16.67 & 13.23 \\
$1985-86$ to $1989-90$ & 15.21 & 15.98 \\
$1990-91$ to $1994-95$ & 17.18 & 15.07 \\
$1995-96$ to $1999-2000$ & 18.04 & $16.02 \quad$ (1995-96 $2001-02)$ \\
\hline $2000-01$ to $2003-04$ & 8.11 & \\
\hline
\end{tabular}

Source: Computed from RBI Bulletin, various issues

There was higher growth rate of revenue expenditure in the 1990s, a period when the faster growing economy had lower revenue receipts. During this period the share in Central taxes and grants also declined. The devolution of a higher share to the Panchayats also reflected as higher revenue expenditure as grants are always categorised as revenue expenditure, even though the local bodies might have used it for capital purposes. In addition to this, there is the impact of the implementation of salary and pension revision in consequence to the recommendations of the Fifth Pay Commission. During the period 2000-01 to 2003-04, the growth in revenue expenditure has been contained. This has been mainly through compression of the Plan expenditure and the one-time rise in 2002-03 is due to a higher plan allocation for the Tenth Five Year Plan. Salary is a substantial portion of the revenue expenditure in Kerala 
(as in other States) due to the spending on social services, especially education and health in which, salary expenditure to the personnel is the major component.

Till the 1980s, 70 percent of the revenue expenditure was developmental expenditure, but this has declined since the 1980s and it is marked in the years since $2000-01^{22}$. It is also pertinent to note that the spending on education and public health, which have made significant contributions in the unique development experience of Kerala have also declined considerably since 2000-01.

Table 10: Education, Health and Development Expenditure as a proportion of Revenue Expenditure

\begin{tabular}{l|r|r|c}
\hline Period & Education & Health & $\begin{array}{c}\text { Development Exp/ } \\
\text { Revenue Exp }\end{array}$ \\
\hline 1957-58 to $1969-70$ & 35.32 & 10.18 & 69.25 \\
$1970-71$ to $1979-80$ & 36.80 & 10.28 & 70.90 \\
$1980-81$ to $1989-90$ & 30.27 & 8.63 & 69.43 \\
$1990-91$ to $1999-00$ & 28.37 & 7.06 & 60.35 \\
$2000-01$ to $2003-04$ & 20.53 & 4.99 & 52.81 \\
\hline
\end{tabular}

Source: Computed from RBI Bulletin, various issues

\section{An Analysis of the Imbalances in the Revenue Budget}

It is discernible from the revenue account that it has been in deficit except for 11 years, during the 46-year period from 1957-58 to 2003-04 (Table 11). Since 1983-84, the State has had a persistent revenue deficit. In other words, total revenue receipts, which consist of the State's own tax revenue, Central devolution of taxes, State's own non-tax revenues and Central devolution of grants have not been able to cover the revenue expenditure, leaving nothing for capital expenditure. A substantial part of the revenue expenditure is also covered by borrowing. 
Table 11: Revenue Deficits and Surplus in Kerala 1957-58 to 2003-04 (in lakhs)

\begin{tabular}{l|c|c|c|c|c|c|c}
\hline $1957-58$ & -142 & $1970-71$ & -1298 & $1983-84$ & -5820 & $1996-97$ & -64304 \\
$1958-59$ & -41 & $1971-72$ & -741 & $1984-85$ & -1367 & $1997-98$ & -112293 \\
$1959-60$ & -274 & $1972-73$ & -695 & $1985-86$ & -3759 & $1998-99$ \\
$1960-61$ & -76 & $1973-74$ & -1965 & $1986-87$ & -15224 & $99-2000$ \\
$1961-62$ & -641 & $1974-75$ & 31 & $1987-88$ & -19459 & $2000-01$ \\
$1962-63$ & -32 & $1975-76$ & -349 & $1988-89$ & -16394 & $2001-02$ \\
$1963-64$ & 134 & $1976-77$ & -330 & $1989-90$ & -25065 & $2002-03$ \\
$1964-65$ & 601 & $1977-78$ & 2905 & $1990-91$ & -42201 & $2003-04$ \\
$1965-66$ & 27 & $1978-79$ & 4300 & $1991-92$ & -36433 & -36805 \\
$1966-67$ & 1016 & $1979-80$ & 5793 & $1992-93$ & -33744 & \\
$1967-68$ & 242 & $1980-81$ & -2722 & $1993-94$ & -37160 & \\
$1968-69$ & 4473 & $1981-82$ & 9598 & $1994-95$ & -39988 & \\
$1969-70$ & -1424 & $1982-83$ & 2678 & $1995-96$ & -40281 & \\
\hline
\end{tabular}

Source: Computed from RBI Bulletin, various issues 
Table 12: Revenue Deficit as a proportion of SDP 1960-61 to 2003-04

\begin{tabular}{l|c|c|c|c|c|c|c|c|c}
\hline $1960-61$ & 0.12 & $1970-71$ & 0.77 & $1980-81$ & 0.55 & $1990-91$ & 2.31 & $2000-01$ & 4.52 \\
$1961-62$ & 0.92 & $1971-72$ & 0.38 & $1981-82$ & NA & $1991-92$ & 1.75 & $2001-02$ & 3.42 \\
$1962-63$ & 0.04 & $1972-73$ & 0.29 & $1982-83$ & NA & $1992-93$ & 1.41 & $2002-03$ & 5.09 \\
$1963-64$ & NA & $1973-74$ & 0.71 & $1983-84$ & 0.78 & $1993-94$ & 1.28 & $2003-04$ & 4.08 \\
$1964-65$ & NA & $1974-75$ & 0.01 & $1984-85$ & 0.17 & $1994-95$ & 1.13 & & \\
$1965-66$ & NA & $1975-76$ & 0.11 & $1985-86$ & 0.42 & $1995-96$ & 0.99 & & \\
$1966-67$ & NA & $1976-77$ & 0.10 & $1986-87$ & 1.52 & $1996-97$ & 1.43 & & \\
$1967-68$ & NA & $1977-78$ & NA & $1987-88$ & 1.75 & $1997-98$ & 2.20 & & \\
$1968-69$ & NA & $1978-79$ & NA & $1988-89$ & 1.27 & $1998-99$ & 3.57 & & \\
$1969-70$ & 0.86 & $1979-80$ & NA & $1989-90$ & 1.70 & $1999-2000$ & 5.74 & & \\
\hline
\end{tabular}

Source: Computed from RBI Bulletin, various issues 
The revenue deficit as a proportion of SDP crossed 1 percent of SDP in 1986-87 (Table 12). During the first half of the 1990s when the SDP was growing at a fast pace, it fell, but increased in the latter half as the growth of revenue expenditure was increasing when the growth of revenue receipts was falling. The three main components of the revenue expenditure are salary, pensions and interest payments and it is not possible to contain them in the short run. Attempts can be made only to contain these in the medium and long run ${ }^{23}$.

Let us take a look at the trend in the growth of capital expenditure during the period 1958-59 to 2003-04. The trend growth rate of capital expenditure has been much lower since the latter half of the 1980s, when buoyancy of revenue receipts started falling and revenue expenditure was sought to be financed through borrowing. Since 1987-88, there has been consistent surplus in the capital account and deficit in the revenue account, clearly indicating that the money borrowed was being spent for revenue expenditure (Table 13). ${ }^{24}$ The burden of any fiscal adjustment has fallen on capital expenditure.

Figure 7. Trend Growth rate of Capital Expenditure 1958-59 to 2002-03

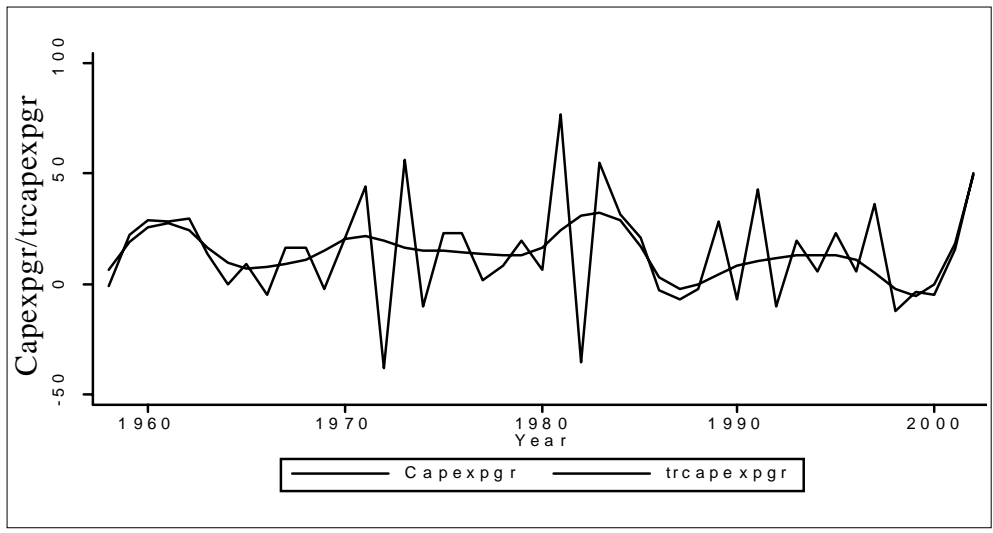

Source: Computed from RBI Bulletin, various issues 
Table 13: Capital Deficits/Surpluses in Kerala: 1957-58 to 2002-03 (in lakhs)

\begin{tabular}{l|r|l|l|l|l|l|r}
\hline $1957-58$ & 223 & $1970-71$ & 314 & $1983-84$ & 3525 & $1996-97$ & 66393 \\
$1958-59$ & 134 & $1971-72$ & -2942 & $1984-85$ & -6352 & $1997-98$ & 83775 \\
$1959-60$ & -10 & $1972-73$ & 9867 & $1985-86$ & 19479 & $1998-99$ & 166449 \\
$1960-61$ & 100 & $1973-74$ & 463 & $1986-87$ & -1883 & $99-2000$ & 360441 \\
$1961-62$ & -30 & $1974-75$ & 1187 & $1987-88$ & 18815 & $2000-01$ & 272707 \\
$1962-63$ & 586 & $1975-76$ & -1282 & $1988-89$ & 11704 & $2001-02$ & 282757 \\
$1963-64$ & -305 & $1976-77$ & -1159 & $1989-90$ & 22601 & $2002-03$ \\
$1964-65$ & 369 & $1977-78$ & -516 & $1990-91$ & 40556 & 391262 \\
$1965-66$ & 383 & $1978-79$ & 2287 & $1991-92$ & 31631 & & \\
$1966-67$ & -1096 & $1979-80$ & -3705 & $1992-93$ & 42748 & & \\
$1967-68$ & -731 & $1980-81$ & -4205 & $1993-94$ & 47081 & & \\
$1968-69$ & -654 & $1981-82$ & -15791 & $1994-95$ & 79951 & & \\
$1969-70$ & 969 & $1982-83$ & 418 & $1995-96$ & 46780 &
\end{tabular}

Source: Computed from RBI Bulletin, various issues 
Before proceeding to the next section, let us also briefly look at the size of government in the State by taking the total expenditure as a proportion of SDP as its proxy. ${ }^{25}$ The total expenditure places commitments of revenue and debt and hence used as a measure of the size of the government ${ }^{26}$.

Table 14: Total expenditure as a Proportion of SDP

\begin{tabular}{l|c|c|c}
\hline Period & $\begin{array}{c}\text { Total } \\
\text { Expenditure/ } \\
\text { SDP }\end{array}$ & $\begin{array}{c}\text { Revenue } \\
\text { expenditure/ } \\
\text { SDP }\end{array}$ & $\begin{array}{c}\text { Capital } \\
\text { Expenditure/SDP }\end{array}$ \\
\hline $1960 \mathrm{~s}$ & 0.12 & 0.08 & 0.04 \\
$1970 \mathrm{~s}$ & 0.14 & 0.10 & 0.04 \\
$1980 \mathrm{~s}$ & 0.19 & 0.15 & 0.04 \\
$1990 \mathrm{~s}$ & & 0.16 & 0.03 \\
\hline till 2001-02) & 0.18 &
\end{tabular}

Source: Computed from RBI bulletin, various issues.

The revenue expenditure as a proportion of SDP has been rising, especially in the 1980s. The proportion of capital expenditure has been stagnant from the 1960s till the 1980s and declined during the 1990s. In view of the revenue side constraints, the revenue expenditure has been financed through borrowing at rising interest rates. The government has been borrowing from the Public Account ${ }^{27}$ and also from welfare boards like Toddy Tappers Welfare Board to tide over cash constraints, at very high rates of interest ${ }^{28}$. This leads to an unsustainable fiscal situation. But instead of a deficit targeting based method, which does not take into account the quality of expenditure, Kerala needs a revenue led fiscal consolidation, with due regard to efficiency in expenditure. The size of government measured by the proportion of total expenditure to the SDP has come down in the 1990s when compared to the $1980 \mathrm{~s},{ }^{29}$ lending strength to the argument that the fiscal consolidation needs to be revenue led. 


\section{Hurdles in seeking a way out of the Chronic Revenue Imbalance}

The deficit in the revenue account has become quite chronic in the past two decades. The major contributor to this is the falling tax buoyancy despite an increasing growth of SDP. The major reason for this is that the fastest growing sectors of the economy are outside the taxing powers of the State.

At this point of time, Kerala along with 21 other States has shifted to the Value Added Tax (VAT) System, though the Sales Tax Act still exists. The argument in favour of VAT is that it would bring the entire chain of input transactions within the tax net, albeit with input tax credit and scope for evasion will come down. There is also rate harmonisation across the States. On the other hand, apart from the crucial question of States' autonomy in fixing tax rates, there is the problem of high cost of detection of evasion through bogus invoices and misuse of input credits. At this moment, this major policy shift makes any prediction of revenue performance even in the near future impossible.

As far as the non-tax revenues are concerned, various committees of the Government have identified areas from which increasing revenue can be mobilised. Even if the amounts targeted are mobilised fully, it will not make a substantial dent in the imbalances in the revenue account. As regards curtailing expenditure, the programme has to be necessarily medium and long term as in the short run committed expenditure, especially non-plan revenue expenditure, cannot be cut.

\section{Sustaining the Developmental Role- Emerging Questions}

Given these hurdles, spending for maintaining the quality and upgrading the social and economic services becomes difficult ${ }^{30}$. In addition to this, a situation has been created where the State is not able to pay arrears of pension to the beneficiaries of many of the unique and pioneering social security schemes in the unorganised sector, initiated earlier. Though the total fiscal burden of these on going pension schemes is 0.24 and 2.27 percent of the SDP and the revenue receipts respectively 
during the financial year 2002-03, it is these payments, in which per capita benefit is quite meagre, that bear the brunt of treasury controls due to liquidity problems of the State.

The deficit targeting approach. i.e. requirement to contain deficits as a proportion of SDP to a limited level in a time-bound manner has now become a legislative commitment. With political economic constraints like strident resistance from dominant class formations like rich traders, in considering the route of revenue mobilisation and the fall in Central devolution of taxes and grants, the easier route of expenditure cuts would be attempted. This puts into danger the achievements in the field of primary education, health care and social security benefits, which gave Kerala a pride of place in the map of human development indicators ${ }^{31}$.

Chronic revenue deficits, decline of developmental expenditure as a proportion of total expenditure and a fall in Central devolution of taxes and grants have been the major fiscal problems for all the States during the 1990s. In fact, the Centre's own tax GDP ratio has fallen from 10 to 11 percent in the beginning of the 1990 s to 8 to 9 percent at present $^{32}$. The fall in Centre's tax-GDP ratio has had an adverse impact on devolution of resources to the States.

If services are kept out of the States's tax net ${ }^{33}$, the faster economic growth will not act as a resource base and the rising expenditure commitments, especially the non-developmental ones will result in chronic deficits in the revenue account. Apart from reforming the existing tax administration and tap the present taxes in a better way, the taxing powers of the States including Kerala have to be enlarged to capture the faster growing sectors of the economy. This calls for a restructuring the fiscal relationships between the Centre and the States.

Being society with a high level of political mobilisation and as a sub-national entity, which chartered a path of development by state provisioning of basic needs, the future of Kerala's development experience needs special consideration. A state hamstrung by fiscal constraints and required to adopt deficit targeting approach to fiscal 
correction will have fewer options than to retreat from the efforts of providing basic needs on a universal basis. This will result in restriction of access to basic needs, which will become commodified and out of reach for the poorer sections of the needy. Though with higher per capita incomes, (which can be due to the income increases in the hands of certain sections only) ${ }^{34}$ Kerala may have a higher economic growth, the development experience, which was pioneered by the state efforts may well become a thing of the past. This type of economic growth will find it hard to pass the touchstone of virtuosity. Retreat of state provisioning can lead to exclusion of large sections of society from access to entitlements for a higher quality of life. The basic cause of the retreat of the state is the fiscal dispossession arising from lack of powers to mobilise adequate revenues from the increasing incomes and the political economic constraint in tapping fully the existing tax potential. But in a relative frame, Kerala has tapped its tax potential better than many other States. It has a very strong reason to demand powers to tax the services sector, the fastest growing sector of its economy.

R. Mohan belongs to the Indian Revenue Service, and was on a deputation to the Centre for Development Studies, Thiruvananthapuram till recently.

E-mail:prakil@rediffmail.com

D. Shyjan is Doctoral Scholar at the Centre for Development Studies, Thiruvananthapuram. His areas of research interests include Economic growth and development experience of Indian States.

E-mail:shyjan@cds.ac.in 


\section{Notes}

1 This stage of higher per capita incomes co-existing with higher level of human development indicators has been described by some observers as 'Virtuous cycle of growth'. See Pushpangadan (2003) for a discussion.

2 The Balance from Current Revenues (BCR) is the difference between the Revenue Receipts excluding Plan grants and the Non-Plan Revenue expenditure. The surplus from BCR is the State's own resources available for financing Plan expenditure. If this is negative, the entire Plan outlay other than Plan grants will be financed out of borrowed funds.

3 Under Article 270 as it originally existed, the revenues from Personal Income Tax were mandatorily shareable with the States and the excise duty at the option of the Union. The other two important taxes, Corporation tax and the Customs duty were not shareable with the States. The surcharges and Cess levied by the Centre were also not shareable. But after the Eightieth Constitutional amendment, the divisible pool consists of all taxes and duties, other than surcharges and cess and a prescribed portion of them is shareable with the States. The Eightyeighth amendment, which introduced Article 268A, has excluded Service tax levied by the Centre from the divisible pool of taxes.

4 Plan grants are devolved from the Planning Commission to meet the revenue component of the Plans and the Non-Plan grants are devolved on the basis of the Finance Commission recommendations. The Plan funds till now were devolved on the basis of what is known as the Gadgil formula. The 70 percent of the funds are loans from the Centre and 30 percent grants. This is based on the implicit assumption that 70 percent of the Plan expenditure is capital in nature and 30 percent revenue. Prior to 1969 , the plan funds were devolved on a project-to-project basis. The Twelfth Finance Commission has recommended that Centre need only devolve Plan grants and need not tie the grant and loan component together as in the Gadgil formula. The States should have the option of borrowing from the market or the Centre. The recommendation has been accepted by the Central Government.

5 This will not be reflected in cases of measurement problems and tax evasion. In some types of tax evasion, when the output of a sector (like turnover) is collected from official sources the part of the turnover evaded 
will not get reflected and to that extent there will be underestimation of domestic output in the economy. The problems in estimation can be there for other indicators like consumption expenditure.

Patnaik (1991) states, "the expenditure stimulated by remittances could not have its demand generating effects confined to Kerala alone. A good deal of it leaked out to neighbouring Tamil Nadu, where wages were low and production centres already existed. A large amount of construction material, for instance is imported into Kerala from Tamil Nadu to meet requirements of the construction boom"

7 Since the SDP measured in current prices of different series differ, they have been spliced to the 1993-94 series at current prices.

A simple comparison of tax-SDP ratios across States will not be correct as structure of the tax base or taxable capacity proxied by SDP can be different. Models like regression method and Representative Tax System are used to compare the tax effort of different States and countries. (See Bahl 1972 for a discussion).

9 The 'Budget in Brief' published by the Government of Kerala uses the terms Average Propensity to tax and Marginal Propensity to tax for these two indicators.

10 See Bahl (1972) and Mansfield (1972) for a discussion. While measuring tax elasticity, the impact of the discretionary changes is taken out using Prest's formula. In buoyancy, impact of discretionary changes and automatic response to the growth of tax base are both captured.

11 We have taken the data of consumption expenditure from Rakhee 2003:P.25, Table 11.

12 In the seminar in which this paper was presented, a question was raised whether the tax buoyancy of above one meant 1) the tax administration is efficient and/or 2) the indicator used as the economic base SDP is not a good one. We have considered both aspects. It is quite possible that tax buoyancy can be greater than one for reasons other than tax administration efficiency alone. A fluctuation in the growth rates of Sales tax as it happened in the 1970s can lead to a higher figure of buoyancy. Despite problems with tax administration efficiency, tax buoyancy has been more 
than one for the Centre as well as many States. When we use consumption expenditure also, the buoyancy has been above one. As regards SDP, for want of a better or more reliable indicator with uses for comparison, it is preferred. See also the Report of the Twelfth Finance Commission for a discussion.

13 The underlying trend is found after removing cyclical and irregular fluctuations in the growth rate. In this paper, this has been found by a process of weighted compound median smoothing using STATA 7.0.

14 The tax buoyancy is high at 2.22 in the second half of the 1970 s. This is the period when the sectoral share of manufacturing and services started rising and that of the primary sector started falling (See Figure 2). Intially, the rise in the share of trade and manufacturing should have contributed partly to the rise in tax buoyancy. There is also the reason of wide fluctuation in growth rate of sales tax during this period.

15 Sales Tax is essentially levied on the sale and purchase of commodities and the output of the trade sub-sector can be taken as a proxy base. As far as manufacturing is concerned, it will be the base of first point levy as well as for the Central Sales tax collected by the State on inter-State trade.

16 Here we are restricting the time period due to non-availability of comparable sectoral SDP data for earlier periods.

17 International petroleum prices went up in 1973 and in 1990 and there was a rise in domestic prices also. Petroleum products contribute substantially to the sales tax revenue of the State. But commodity wise break up of sales tax revenues are not available, as stated in the Report of the Resources Commission (1993). Discussion with informed sources of the sales tax department reveal that sales tax on petroleum products together with excise duty on liquor contribute 50 percent of the own tax revenues of the State.

18 The Twelfth Finance Commission has devolved service tax also to the States as the notification consequent to the amendment has not been issued. But the Finance Commissions in future will not be able to devolve proceeds of the service tax to the States. The Twelfth Finance Commission 
has made a recommendation that the once the notification is issued, it should be ensured that the share to the States from service tax should not go below the existing one.

19 When the power to tax services is devolved to the States, certain problems can arise. If the service inputs are given credit while computing the Central Excise Duty, the question to be addressed is whether the Centre will be willing to give credit to the service tax paid to the States. The Centre might not easily accept giving up powers to tax services as well as to give credit to the service tax paid to the States. There have been suggestions to bring goods and services comprehensively under a single tax instead of taxing them separately (Rao 2001). The Kelkar Task Force(2004) suggested a national level goods and services tax, with the Centre and the States sharing the same tax base. Another option will be to devolve the service tax to the States and adjust the credit given to service inputs from the devolution of net proceeds from the Centre to the States.

20 The Resources Commission (1993) and the White Paper on State Finances (2001) have discussed about the explicit and implicit subsidies. The Resources Commission report has stated that a substantial portion of the subsidies is in the social sector and of these two thirds is in the educational sector. The levy of user charges in social and economic services can be an important source of non-tax revenue. We are not discussing the headwise details here.

21 See Second report of the Ninth Finance Commission, Chapter VII, 'Grants-in- Aid, Pp. 27-29

22 When the share of developmental expenditure in the revenue budget is high in previous time periods, i.e. expenditure on education, health, public works etc., non-developmental expenditure in subsequent time periods is bound to increase. The reason for this is that a substantial portion of the developmental expenditure, especially in the social sector, is salary expenditure as these are personnel oriented services. In later periods, the superannuation and retirement benefits paid to them will be categorised as non-developmental expenditure.

23 For suggestions, see Report of the Second State Finance Commission (2000) and White Paper on State Finances (2001). 
24 We do not argue here that by merely increasing capital expenditure, the quality of fiscal management will improve. If we cannot raise user charges or be able to obtain revenue receipts at least to the extent of financing the interest payment burden and meeting maintenance expenditure, increase in capital expenditure will also induce a fiscal burden.

25 This will not be an exact measure as government can influence through regulatory functions, which actually do not get reflected in the expenditure. See Slemrod (1995) for a discussion.

26 When compared to the Central government and all States' average, Kerala's total expenditure as a proportion of SDP is not higher.

27 The Centre as well as the States have the Consolidated Fund, the Contingency Fund and the Public Account. The Public Account consists of the moneys, which the government holds in fiduciary capacity, like the small savings, provident fund etc.

28 See the Report of the Resources Commission (1993).

29 The proportion of revenue expenditure has gone up during the 1990s. We have separately discussed the reasons for this and also the difficulty in cutting committed expenditure in the short run. While emphasising on efficiency in expenditure, it is considered that revenue-led fiscal consolidation is preferable to deficit targeting approach, in which, the quality of expenditure that is being cut is not given importance.

30 As discussed in the paper, committed expenditure cannot be cut. With problems in revenue moblisation and deficit targeting becoming a legislative commitment, the expenditure reduction in social and economic services becomes the first option for containing deficits. The argument of private sector taking the place of public provisioning will also be advanced. There are debatable points in this, the details of which are beyond the scope of our discussion. For an analysis, see Leys (2001).

31 In the seminar on $23 / 05 / 2005$ in which this paper was presented, an argument was raised that the achievements in human development indicators could be sustained despite the reduced level of state intervention. In support of the argument, it was pointed out that despite the declining share of developmental expenditure, Kerala has been 
achieving better human development indicators than other States. It has to be taken note of that the adverse impact of the retreat of the state will be felt only after a lag period. Still, it need not get reflected in the relative position because, the fiscal constraints operate for other States also. Since most of the private sector initiatives in education and health are for catering to the needs of people who can afford high costs, it will exclude a vast majority from the benefits of this. The state retreat from these fields can accentuate this problem and adverse impact on human development indicators is bound to follow.

32 See Mohan (2004) and Report of the Kelkar Task Force (2004) for a detailed discussion

33 A point that came up for discussion on this paper was that suggestion for emphasis on resource mobilisation essentially means more taxes and it can have distortionary effects. Though an analysis of relative distortionary effects of different taxes and optimal taxation is an area wide enough for a separate analysis, we would like to clarify that we are not suggesting any fresh taxes. The suggestion is for shifting of the taxation on services from the Centre to the States.

34 The higher level of per capita income is due to impact of remittances also and only 17.6 percent of Kerala's households received remittances (Zachariah and Irudaya Rajan 2004). 


\section{References}

Bahl, Roy W. (1972), 'A Representative Tax System Approach to Measuring Tax Effort in Developing Countries', IMF Staff Papers, Vol.XIX No.1, Pp. 87--124

Centre for Development Studies (1975), Poverty, Unemployment and Development Policy: A Case Study of Selected Issues with References to Kerala, United Nations, New York.

Dreze, Jean and Sen, Amartya (1989), 'Hunger and Public Action', Oxford, Claredon Press.

Economic and Political weekly Research Foundation (EPWRF) (2003), Domestic Product of States of India: 1960-61 to 2000-01, Sameeksha Trust, Mumbai.

Franke, Richard and Chasin, Barbara (1991), 'Kerala: Development Through Radical Reform' and Four Comments on Kerala', Monthly Review, New York, January.

George, K.K (1999), Limits to Kerala Model of Development: An Analysis of Fiscal Crisis and its Implications, Centre for Development Studies, Thiruvananthapuram.

Government of India (2004), Report of the Task Force on implementation of FRBM Act 2003, Chairman Dr.Vijay Kelkar.

Government of India, Reports of the Ninth, Eleventh and Twelfth Commissions.

Government of Kerala, Budget in Brief - 2005-2006.

Government of Kerala (1993), Report of the Resources Commission.

Government of Kerala (2000), Report of the Second State Finance Commission.

Government of Kerala (2001), White Paper on State Finances. 
Government of Kerala (1969), Report of the Taxation Enquiry Committee.

Gulati, I. S (1994), Introduction in Sebastian, Jose (1994), 'Commodity Tax Performance: A Study in the Context of Fiscal Federalism', Sujan Publications, Calcutta.

Kannan, K. P and Hari, K. S. (2002), 'Kerala's Gulf Connection: Emigration, Remittances and their Macroeconomic Impact 19722000', Working Paper No. 328, Centre for Development Studies, Thiruvananthapuram.

Leys, Colin (2001), Market-Driven Politics: Neoliberal Democracy and Public Interest, Verso Books, London, New York.

Mansfield, Charles Y (1972), 'Elasticity and Buoyancy of a Tax System: A Method Applied to Paraguay', IMF Staff Papers, Vol.XIX No.2, Pp.425--441

Mohan, R. (2004), 'Central Finances in India- Alternative to Procrustean Fiscal Correction,' Working Paper No. 365, Centre for Development Studies, Thiruvananthapuram.

Osmani, S.R (1988), 'Social Security in Asia', No.18, April, The Development Economics Research Programme, WIDER, Helsinki

Patnaik, Prabhat (1991), 'Four Comments on Kerala', January, Monthly Review, Pp 33-37 New York.

Pushpangadan, K (2003), 'Remittances, Consumption and Economic Growth in Kerala: 1980-2000', Working Paper No.343, Centre for Development Studies, Thiruvananthapuram.

Rakhee P. B (2003), 'Estimation of Tax Leakage and its Impact on Fiscal Health in Kerala', Working Paper No.347, Centre for Development Studies, Thiruvananthapuram.

Ravi Raman, K. (2004), 'The Asian Development Bank Loan for Kerala (India): The Adverse implications and Search for Alternatives', 
Working Paper No.357, Centre for Development Studies, Thiruvananthapuram.

Rao, Govinda M. (2001), 'Taxing Services: Issues and Strategy', Economic and Political Weekly, October 20, Pp.3999-4006.

Reserve Bank of India, RBI Bulletin, various issues.

Sebastian, Jose (1994), 'Commodity Tax Performance: A study in the Context of Fiscal Federalism', Sujan Publications, Calcutta.

Slemrod, Joel (1995), 'What Do Cross-country Studies Teach about Government Involvement, Prosperity and Economic Growth?' Brookings Papers on Economic Activity, 2, Pp 373-431.

Zachariah, K.C. and Irudaya Rajan. S. (2004), 'Gulf Revisited', Working Paper No.363, Centre for Development Studies, Thiruvananthapuram. 


\section{CENTRE FOR DEVELOPMENT STUDIES LIST OF WORKING PAPERS \\ [New Series]}

The Working Paper Series was initiated in 1971. A new series was started in 1996 from WP. 270 onwards. Working papers beginning from 279 can be downloaded from the Centre's website (www.cds.edu)

W.P. 374 K. C. ZACHARIAH, S. IRUDAYA RAJAN. Unemployment in Kerala at the Turn of the Century: Insights from CDS Gulf Migration Studies. August 2005.

W.P. 373 SUNIL MANI, The Dragon vs. The Elephant Comparative Analysis of Innovation Capability in the Telecommunications Equipment Industry in China and India. July 2005

W.P. 372 MOTKURI VENKATANARAYANA On The Non-Random Distribution of Educational Deprivation of Children in India. July 2005

W.P. 371 DIBYENDU S. MAITI Organisational Morphology of Rural Industries in Liberalised India: A Study of West Bengal. June 2005

W.P. 370 SUNIL MANI, Keeping Pace with Globalisation Innovation Capability in Korea's Telecommunications Equipment Industry. March 2005.

W.P. 369 V.R. PRABHAKARAN NAIR, Determinants of Fixed Investment: A Study of Indian Private Corporate Manufacturing Sector. March 2005.

W.P. 368 J. DEVIKA, Modernity with Democracy? : Gender and Governance in the People's Planning Campaign, Keralam. February 2005

W.P. 367 VINEETHA MENON, ANTONYTO PAUL, K N NAIR Dynamics of Irrigation Institutions: Case study of a Village Panchayat in Kerala. February 2005

W.P. 366 VIJAYAMOHANAN PILLAI N. Causality and Error Correction in Markov Chain: Inflation in India Revisited. December 2004.

W.P. 365 R. MOHAN. Central Finances in India - Alternative to Procrustean Fiscal Correction. November 2004. 
W.P. 364 SUNIL MANI. Coping with Globalisation Public R\&D Projects in Telecommunications Technologies in Developing Countries. November 2004.

W.P.363 K C ZACHARIAH, S IRUDAYA RAJAN. Gulf Revisited Economic Consequences of Emigration From Kerala, Emigration and Unemployment. September 2004.

W.P.362 M. VENKATANARAYANA. Educational Deprivation of Children in Andhra Pradesh, Levels and Trends, Disparities and Associative Factors. August 2004.

W.P. 361 K.P. KANNAN, VIJAYAMOHANAN PILLAI N. Development as a Right to Freedom: An Interpretation of the Kerala Model. August 2004.

W.P. 360 VIJAYAMOHANAN PILLAI N. CES Function, Generalised Mean and Human Poverty Index: Exploring Some Links. July 2004.

W.P. 359 PRAVEENA KODOTH, Shifting the Ground of Fatherhood: Matriliny, Men and Marriage in Early Twentieth Century Malabar. May 2004.

W.P. 358 MRIDUL EAPEN. Women and Work Mobility: Some Disquieting Evidences from the Indian Data. May 2004.

W.P. 357 K. RAVI RAMAN. The Asian Development Bank Loan for Kerala (India): The Adverse Implications and Search for Alternatives, March 2004.

W.P. 356 VIJAYAMOHANAN PILLAI N. Liberalisation of Rural Poverty: The Indian Experience, March 2004.

W.P. 355 P.L.BEENA Towards Understanding the Merger-Wave in the Indian Corporate Sector: A Comparative Perspective, January 2004.

W.P. 354 K.P. KANNAN AND R. MOHAN India's Twelfth Finance Commission A View from Kerala, December 2003.

W.P. 353 K.N. HARILAL AND P.L. BEENA The WTO Agreement on Rules of Origin Implications for South Asia, December 2003.

W.P. 352 K. PUSHPANGADAN Drinking Water and Well-being In India: Data Envelopment Analysis, October 2003.

W.P. 351 INDRANI CHAKRABORTY Liberalization of Capital Inflows and the Real Exchange Rate in India : A VAR Analysis, September 2003.

W.P. 350 M.KABIR Beyond Philanthropy: The Rockefeller Foundation's Public Health Intervention in Thiruvithamkoor, 1929-1939, September 2003. 
W.P. 349 JOHN KURIEN The Blessing of the Commons : Small-Scale Fisheries, Community Property Rights, and Coastal Natural Assets, August 2003.

W.P. 348 MRIDUL EAPEN, Rural Industrialisation in Kerala: ReExamining the Issue of Rural Growth Linkages, July 2003.

W.P. 347 RAKHE PB, Estimation of Tax Leakage and its Impact on Fiscal Health in Kerala, July 2003.

W.P. 346 VIJAYAMOHANAN PILLAI N, A contribution to Peak load pricing theory and Application. April 2003.

W.P. 345 V.K. RAMACHANDRAN, MADHURA SWAMINATHAN, VIKAS RAWAL Barriers to Expansion of Mass Literacy and Primary Schooling in West Bengal: Study Based on Primary Data from Selected Villages. April 2003.

W.P. 344 PRADEEP KUMAR PANDA Rights-Based Strategies in the Prevention of Domestic Violence, March 2003.

W.P. 343 K. PUSHPANGADAN Remittances, Consumption and Economic growth in Kerala: 1980-2000, March 2003.

W.P. 342 D NARAYANA Why is the Credit-deposit Ratio Low in Kerala? January 2003.

W.P. 341 MRIDUL EAPEN, PRAVEENA KODOTH Family Structure, Women's Education and Work: Re-examining the High Status of Women in Kerala. November 2002.

W.P. 340 J. DEVIKA, Domesticating Malayalees: Family Planning, the Nation and Home-Centered Anxieties in Mid-20 ${ }^{\text {th }}$ Century Keralam. October, 2002.

W.P. 339 M PARAMESWARAN, Economic Reforms and Technical Efficiency: Firm Level Evidence from Selected Industries in India. October, 2002.

W.P. 338 PRAVEENA KODOTH, Framing Custom, Directing Practices: Authority, Property and Matriliny under Colonial Law in Nineteenth Century Malabar, October 2002.

W.P. 337 K.NAVANEETHAM, Age Structural Transition and Economic Growth: Evidence From South and Southeast Asia, August 2002.

W.P. 336 PULAPRE BALAKRISHNAN, K. PUSHPANGADAN, M. SURESH BABU, Trade Liberalisation, Market Power and Scale Efficiency in Indian Industry, August 2002.

W.P. 335 J. DEVIKA, Family Planning as 'Liberation': The Ambiguities of 'Emancipation from Biology' in Keralam July 2002. 
W.P. 334 E. ABDUL AZEEZ, Economic Reforms and Industrial Performance an Analysis of Capacity Utilisation in Indian Manufacturing, June 2002.

W.P. 333 K. PUSHPANGADAN Social Returns from Drinking Water, Sanitation and Hygiene Education: A Case Study of Two Coastal Villages in Kerala, May 2002.

W.P. 332 K. P. KANNAN, The Welfare Fund Model of Social Security for Informal Sector Workers: The Kerala Experience. April 2002.

W.P. 331 SURESH BABU, Economic Reforms and Entry Barriers in Indian Manufacturing. April 2002.

W.P. 330 ACHIN CHAKRABORTY, The Rhetoric of Disagreement in Reform Debates April 2002.

W.P. 329 J. DEVIKA, Imagining Women's Social Space in Early Modern Keralam. April 2002.

W.P. 328 K. P. KANNAN, K. S. HARI, Kerala's Gulf Connection Emigration, Remittances and their Macroeconomic Impact 19722000. March 2002.

W.P. 327 K. RAVI RAMAN, Bondage in Freedom, Colonial Plantations in Southern India c. 1797-1947. March 2002.

W.P. 326 K.C. ZACHARIAH, B.A. PRAKASH, S. IRUDAYA RAJAN, Gulf Migration Study : Employment, Wages and Working Conditions of Kerala Emigrants in the United Arab Emirates. March 2002.

W.P. 325 N. VIJAYAMOHANAN PILLAI, Reliability and Rationing cost in a Power System. March 2002.

W.P. 324 K. P. KANNAN, N. VIJAYAMOHANAN PILLAI, The Aetiology of the Inefficiency Syndrome in the Indian Power Sector Main Issues and Conclusions of a Study. March 2002.

W.P. 323 V. K. RAMACHANDRAN, MADHURA SWAMINATHAN, VIKAS RAWAL, How have Hired Workers Fared? A Case Study of Women Workers from an Indian Village, 1977 to 1999. December 2001.

W.P. 322 K. C. ZACHARIAH, The Syrian Christians of Kerala: Demographic and Socioeconomic Transition in the Twentieth Century, November 2001.

W.P. 321 VEERAMANI C. Analysing Trade Flows and Industrial Structure of India: The Question of Data Harmonisation, November 2001. 
W.P. 320 N. VIJAYAMOHANAN PILLAI, K. P. KANNAN, Time and Cost Over-runs of the Power Projects in Kerala, November 2001.

W.P. 319 K. C. ZACHARIAH, P. R. GOPINATHAN NAIR, S. IRUDAYARAJAN Return Emigrants in Kerala: Rehabilitation Problems and Development Potential. October 2001

W.P. 318 JOHN KURIEN, ANTONYTO PAUL Social Security Nets for Marine Fisheries-The growth and Changing Composition of Social Security Programmes in the Fisheries Sector of Kerala State, India. September 2001.

W.P. 317 K. J. JOSEPH, K. N. HARILAL India's IT Export Boom: Challenges Ahead. July 2001.

W.P. 316 K.P. KANNAN, N. VIJAYAMOHANAN PILLAI The Political Economy of Public Utilities: A Study of the Indian Power Sector, June 2001.

W.P. 315 ACHIN CHAKRABORTY The Concept and Measurement of Group Inequality, May 2001.

W.P. 314 U.S.MISHRA, MALA RAMANATHAN Delivery Compli-cations and Determinants of Caesarean Section Rates in India - An Analysis of National Family Health Surveys, 1992-93, March 2001.

W.P. 313 VEERAMANI. C India's Intra-Industry Trade Under Economic Liberalization: Trends and Country Specific Factors, March 2001

W.P. 312 N. VIJAYAMOHANAN PILLAI Electricity Demand Analysis and Forecasting -The Tradition is Questioned, February 2001

W.P. 311 INDRANI CHAKRABORTY Economic Reforms, Capital Inflows and Macro Economic Impact in India, January 2001

W.P. 310 K. K. SUBRAHMANIAN. E. ABDUL AZEEZ, Industrial Growth In Kerala: Trends And Explanations November 2000

W.P. 309 V.SANTHAKUMAR, ACHIN CHAKRABORTY, Environmental Valuation and its Implications on the Costs and Benefits of a Hydroelectric Project in Kerala, India, November 2000.

W.P. 308 K. P. KANNAN, N . VIJAYAMOHANAN PILLAI, Plight of the Power Sector in India : SEBs and their Saga of Inefficiency November 2000.

W.P. 307 K. NAVANEETHAM, A. DHARMALINGAM, Utilization of Maternal Health Care Services in South India, October 2000.

W.P. 306 S. IRUDAYA RAJAN, Home Away From Home: A Survey of Oldage Homes and inmates in Kerala, August 2000.

W.P. 305 K. N. HARILAL, K.J. JOSEPH, Stagnation and Revival of Kerala Economy: An Open Economy Perspective, August 2000.

W.P. 304 K. P. KANNAN, Food Security in a Regional Perspective; A View from 'Food Deficit' Kerala, July 2000. 
W.P. 303 K. C. ZACHARIAH, E. T. MATHEW, S. IRUDAYA RAJAN, Socio-Economic and Demographic Consequenes of Migration in Kerala, May 2000.

W.P. 302 K. PUShPANGADAN, G. MURUGAN, Gender Bias in a Marginalised Community: A Study of Fisherfolk in Coastal Kerala, May 2000.

W.P. 301 P. L. BEENA An Analysis of Mergers in the Private Corporate Sector in India, March, 2000.

W.P. 300 D. NARAYANA Banking Sector Reforms and the Emerging Inequalities in Commercial Credit Deployment in India, March, 2000.

W.P. 299 JOHN KURIEN Factoring Social and Cultural Dimensions into Food and Livelihood Security Issues of Marine Fisheries; A Case Study of Kerala State, India, February, 2000.

W.P. 298 D. NARAYANA, K. K. HARI KURUP, Decentralisation of the Health Care Sector in Kerala : Some Issues, January, 2000.

W.P. 297 K.C. ZACHARIAH, E. T. MATHEW, S. IRUDAYA RAJAN Impact of Migration on Kerala's Economy and Society, July, 1999.

W.P. 296 P.K. MICHAEL THARAKAN, K. NAVANEETHAM Population Projection and Policy Implications for Education:A Discussion with Reference to Kerala, July, 1999.

W.P. 295 N. SHANTA, J. DENNIS RAJA KUMAR Corporate Statistics: The Missing Numbers, May, 1999.

W.P. 294 K. P. KANNAN Poverty Alleviation as Advancing Basic Human Capabilities: Kerala's Achievements Compared, May, 1999.

W.P. 293 MRIDUL EAPEN Economic Diversification In Kerala : A Spatial Analysis, April, 1999.

W.P. 292 PRADEEP KUMAR PANDA Poverty and young Women's Employment: Linkages in Kerala, February, 1999.

W.P. 291 P. K. MICHAEL THARAKAN Coffee, Tea or Pepper? Factors Affecting Choice of Crops by Agro-Entrepreneurs in Nineteenth Century South-West India, November 1998

W.P. 290 CHRISTOPHE Z. GUILMOTO, S. IRUDAYA RAJAN Regional Heterogeneity and Fertility Behaviour in India, November 1998.

W.P. 289 JOHN KURIEN Small Scale Fisheries in the Context of Globalisation, October 1998.

W.P. 288 S. SUDHA, S. IRUDAYA RAJAN Intensifying Masculinity of Sex Ratios in India : New Evidence 1981-1991, May 1998.

W.P. 287 K. PUSHPANGADAN, G. MURUGAN Pricing with Changing Welfare Criterion: An Application of Ramsey-Wilson Model to Urban Water Supply, March 1998. 
W.P. 286 ACHIN CHAKRABORTY The Irrelevance of Methodology and the Art of the Possible : Reading Sen and Hirschman, February 1998.

W.P. 285 V. SANTHAKUMAR Inefficiency and Institutional Issues in the Provision of Merit Goods, February 1998.

W.P. 284 K. P. KANNAN Political Economy of Labour and Development in Kerala, January 1998.

W.P. 283 INDRANI CHAKRABORTY Living Standard and Economic Growth: A fresh Look at the Relationship Through the Non- Parametric Approach, October 1997.

W.P. 282 S. IRUDAYA RAJAN, K. C. ZACHARIAH Long Term Implications of Low Fertility in Kerala, October 1997.

W.P. 281 SUNIL MANI Government Intervention in Industrial $R \& D$, Some Lessons from the International Experience for India, August 1997.

W.P. 280 PRADEEP KUMAR PANDA Female Headship, Poverty and Child Welfare : A Study of Rural Orissa, India, August 1997.

W.P. 279 U.S. MISRA, MALA RAMANATHAN, S. IRUDAYA RAJAN Induced Abortion Potential Among Indian Women, August 1997.

W. P. 278 PRADEEP KUMAR PANDA The Effects of Safe Drinking Water and Sanitation on Diarrhoeal Diseases Among Children in Rural Orissa, May 1997.

W. P. 277 PRADEEP KUMAR PANDA Living Arrangements of the Elderly in Rural Orissa, May 1997.

W. P. 276 V. SANTHAKUMAR Institutional Lock-in in Natural Resource Management: The Case of Water Resources in Kerala, April 1997.

W.P. 275 G. OMKARNATH Capabilities and the process of Development March 1997.

W.P. 274 K. PUSHPANGADAN, G. MURUGAN User Financing \& Collective action: Relevance sustainable Rural water supply in India. March 1997.

W.P. 273 ROBERT E. EVENSON, K.J. JOSEPH Foreign Technology Licensing in Indian Industry: An econometric analysis of the choice of partners, terms of contract and the effect on licensees' performance March 1997.

W.P. 272 SUNIL MANI Divestment and Public Sector Enterprise Reforms, Indian Experience Since 1991 February 1997.

W.P. 271 SRIJIT MISHRA Production and Grain Drain in two inland Regions of Orissa December 1996.

W.P. 270 ACHIN CHAKRABORTY On the Possibility of a Weighting System for Functionings December 1996. 


\section{Books Published by the CDS}

Biodiversity, Sustainable Development and Economic Analysis

J. Hans B. Opschoor

CDS, 2004, Rs. 100/\$11

Plight of the Power Sector in India: Inefficiency, Reform and Political Economy

K.P. Kannan and N. Vijayamohanan Pillai

CDS, 2002, Rs. 400/\$40

Kerala's Gulf Connection: CDS Studies on International Labour Migration from Kerala State in India

K.C. Zachariah, K. P. Kannan, S. Irudaya Rajan (eds)

CDS, 2002, pp 232, Hardcover, Rs. 250/\$25

Performance of Industrial Clusters: A Comparative Study of Pump Manufacturing Cluster in Coimbatore (Tamil Nadu) \& Rubber Footwear Cluster in Kottayam (Kerala)

P. Mohanan Pillai

CDS, 2001, pp 158, Paperback, Rs. 175/\$18

Poverty, Unemployment and Development Policy : A Case Study of Selected Issues With Reference to Kerala

United Nations, 2000 (reprint), pp 235

(available for sale in India only), Rs. 275

Land Relations and Agrarian Development in India:A Comparative Historical Study of Regional Variations

Sakti Padhi

CDS,1999. pp 335, Hardcover, Rs. 425/\$48

Agrarian Transition Under Colonialism: Study of A Semi Arid Region of Andhra, C.1860-1900

GN Rao

CDS,1999. pp 133, Paperback, Rs. 170/ \$19

Property Rights, Resource Management \& Governance: Crafting An Institutional Framework for Global Marine Fisheries John Kurien

CDS \& SIFFS, 1998. pp 56, Paperback, Rs. 50/ \$10 
Health, Inequality and Welfare Economics

Amartya Sen

CDS. 1996. pp 26, Paperback, Rs. 70/ \$ 10

Industrialisation in Kerala: Status of Current Research and Future Issues

P Mohanan Pillai \& N Shanta

CDS. 1997. pp 74, Paperback, Rs. 110/ \$ 12

CDS M.Phil Theses (1990/91-1993/94): A Review Vol.II

T T Sreekumar

CDS. 1996. pp 99, Paperback, Rs. 120/\$ 14

Trends In Agricultural Wages in Kerala 1960-1990

A A Baby

CDS. 1996. pp 83, Paperback, Rs. 105/ \$ 12

CDS M.Phil Theses (1975/76-1989/90): A Review Vol.1

G N Rao

CDS. 1996. pp 162, Paperback, Rs. 155/ \$ 18

Growth of Education in Andhra - A Long Run View

C Upendranath

CDS. 1994. pp 158, Paperback, Rs. 135/ \$ 15

Growth of Market Towns in Andhra: A Study of the Rayalseema Region C 1900-C.1945

Namerta

CDS. 1994. pp 186, Paperback, Rs.125/ \$ 14

Floods and Flood Control Policies: an Analysis With Reference to the Mahanadi Delta in Orissa

Sadhana Satapathy

CDS. 1993 pp 98, Paperback, Rs. 110/\$ 12

Growth of Firms in Indian Manufacturing Industry

N Shanta

CDS. 1994. pp 228, Hardcover, Rs. 250/ \$ 28

Demographic Transition in Kerala in the 1980s

K C Zachariah, S Irudaya Rajan, P S Sarma, K Navaneetham, P S Gopinathan Nair \& U S Mishra,

CDS. 1999 (2 ${ }^{\text {nd }}$ Edition) pp 305, Paperback, Rs.250/ \$ 28 
Impact of External Transfers on the Regional Economy of Kerala P R Gopinathan Nair \& P Mohanan Pillai

CDS 1994. pp 36, Paperback, Rs.30/ \$ 10

Urban Process in Kerala 1900-1981

T T Sreekumar

CDS. 1993. pp 86, Paperback, Rs.100/ \$ 11

Peasant Economy and The Sugar Cooperative: A Study Of The Aska Region in Orissa

Keshabananda Das

CDS. 1993. pp 146, Paperback, Rs.140/ \$ 16

Industrial Concentration and Economic Behaviour: Case Study of Indian Tyre Industry

Sunil Mani

CDS. 1993. pp 311, Hardcover, Rs. 300/ \$ 34

Limits To Kerala Model of Development: An Analysis of Fiscal Crisis and Its Implications.

K K George

CDS. 1999 ( $2^{\text {nd }}$ edition) pp 128, Paperback, Rs. 160/ \$ 18

Indian Industrialization: Structure and Policy Issues. (No Stock) Arun Ghosh, K K Subrahmanian, Mridul Eapen \& Haseeb A Drabu (EDs).

OUP. 1992. pp 364, Hardcover, Rs.350/ \$ 40

Rural Household Savings and Investment: A Study of Some Selected Villages

P G K Panikar, P Mohanan Pillai \& T K Sundari

CDS. 1992. pp 144, Paperback, Rs. 50/ \$ 10

International Environment, Multinational Corporations and Drug Policy

P G K Panikar, P Mohanan Pillai \& T K Sundari

CDS. 1992. pp 77, Paperback, Rs.40/ \$ 10

Trends in Private Corporate Savings

N Shanta

CDS. 1991. pp 90, Paperback, Rs. 25/ \$ 10 
Coconut Development in Kerala: Ex-post Evaluation

D Narayana, K N Nair, P Sivanandan, N Shanta and

G N Rao

CDS. 1991. pp 139, Paperback, Rs.40/ \$ 10

Caste and The Agrarian Structure

T K Sundari

Oxford \& IBH. 1991. pp 175, Paperback, Rs.125/ \$ 14

Livestock Economy of Kerala

P S George and K N Nair

CDS. 1990. pp 189, Hardcover, Rs. 95/ \$ 10

The Pepper Economy of India (No Stock)

P S George, K N Nair and K Pushpangadan

Oxford \& IBH. 1989. pp 88, Paperback, Rs. 65/ \$ 10

The Motor Vehicle Industry in India

(Growth within a Regulatory Environment)

D Narayana

Oxford \& IBH. 1989. pp 99, Paperback, Rs. 75/ \$ 10

Ecology or Economics in Cardamom Development (No Stock)

K N Nair, D Narayana and P Sivanandan

Oxford \& IBH. 1989. pp 99, Paperback, Rs. 75/ \$ 10

Land Transfers and Family Partitioning

D Rajasekhar

Oxford and IBH. 1988. pp 90, Hardcover, Rs. 66/ \$ 10

Essays in Federal Financial Relations

I S Gulati and K K George

Oxford and IBH. 1988. pp 172, Hardcover, Rs. 82/ \$ 10

Bovine Economy in India

A Vaidyanathan

Oxford \& IBH. 1988. pp 209, Hardcover, Rs. 96/ \$ 11

\section{Health Status of Kerala}

P G K Panikar and C R Soman

CDS. 1984. pp 159, Hardcover, Rs.100/ \$ 11 \& Paperback, Rs. 75/ \$ 10 


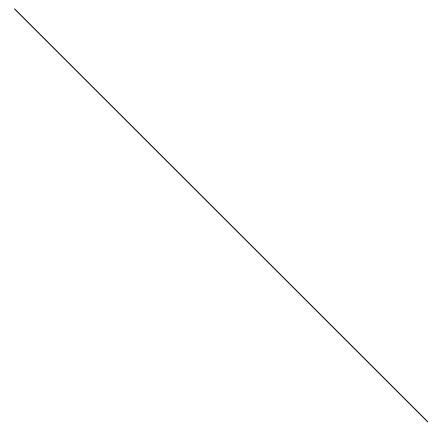


This work is licensed under a

Creative Commons

Attribution - NonCommercial - NoDerivs 3.0 Licence.

To view a copy of the licence please see:

http://creativecommons.org/licenses/by-nc-nd/3.0/ 